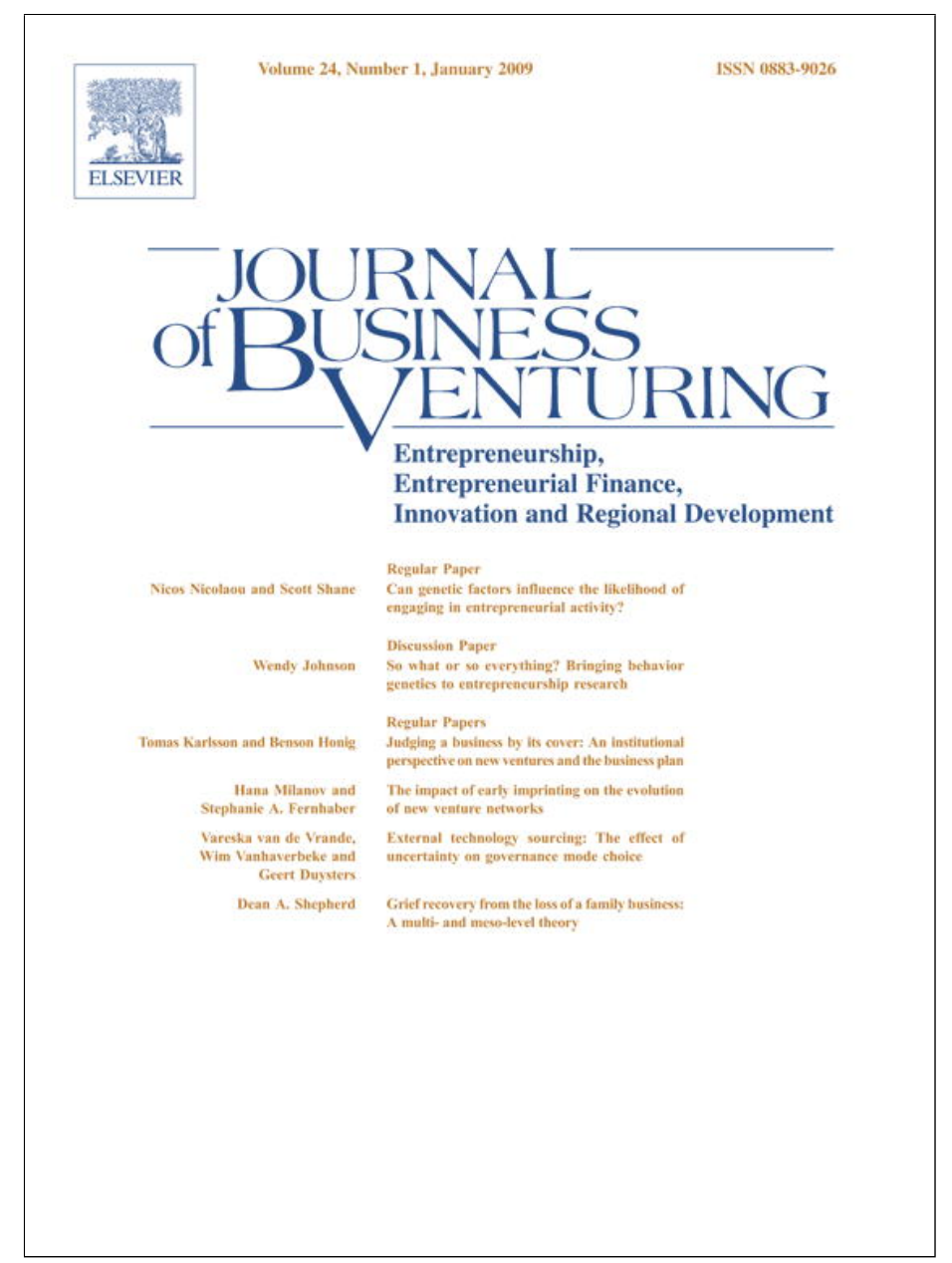

This article appeared in a journal published by Elsevier. The attached copy is furnished to the author for internal non-commercial research and education use, including for instruction at the authors institution and sharing with colleagues.

Other uses, including reproduction and distribution, or selling or licensing copies, or posting to personal, institutional or third party websites are prohibited.

In most cases authors are permitted to post their version of the article (e.g. in Word or Tex form) to their personal website or institutional repository. Authors requiring further information regarding Elsevier's archiving and manuscript policies are encouraged to visit:

http://www.elsevier.com/copyright 


\title{
External technology sourcing: The effect of uncertainty on governance mode choice
}

\author{
Vareska van de Vrande ${ }^{\mathrm{a}, *}$, Wim Vanhaverbeke $^{\mathrm{b}}$, Geert Duysters $^{\mathrm{c}}$ \\ ${ }^{\text {a }}$ RSM Erasmus University, The Netherlands \\ ${ }^{\mathrm{b}}$ Hasselt University, Belgium \\ ${ }^{\mathrm{c}}$ UNU-MERIT and Eindhoven University of Technology, The Netherlands
}

Received 1 September 2006; received in revised form 1 October 2007; accepted 1 October 2007

\begin{abstract}
External knowledge sourcing is increasingly important for corporate entrepreneurship. In this study, we examine the effect of external and relational uncertainty on the governance choice for inter-organizational technology sourcing. We develop a number of hypotheses about the impact of environmental turbulence, technological newness, technological distance and prior cooperation on the choice between different governance modes. Data about external technology sourcing transactions in the pharmaceutical industry do not provide evidence for a continuum from less to more integrated sourcing modes. However, we find that the ranking depends on the type of uncertainty, indicating that firms tackle different types of uncertainty with different governance modes.

(C) 2007 Elsevier Inc. All rights reserved.
\end{abstract}

Keywords: External technology sourcing; Governance modes; Real options theory; Transaction cost theory; External and relational uncertainty

\section{Executive summary}

In today's competitive landscape, the pursuit of corporate entrepreneurship as a vehicle to create new business opportunities is becoming more and more important. Because of the resource implications associated with corporate entrepreneurship, the external sourcing of knowledge is taking a more central role in established companies. In order to access external sources of knowledge, firms can choose from a myriad of different sourcing modes. Innovating companies can choose between these external technology sourcing modes in order to react in a flexible way to new technological developments and changing market conditions. In this paper, we distinguish among corporate venture capital investments, non-equity technology alliances, joint ventures, minority holdings, and mergers and acquisitions. The choice companies have between these modes is largely determined by the uncertainty surrounding the investment decision. We argue that

\footnotetext{
* Corresponding author. RSM Erasmus University, Department of Strategic Management and Business Environment, Room T7-33, P.O. Box 1738, 3000 DR Rotterdam, The Netherlands. Tel.: +31 10408 2208; fax: +31 104089013.

E-mail addresses: vvrande@rsm.nl (V. van de Vrande),wim.vanhaverbeke@uhasselt.be (W. Vanhaverbeke),g.m.duysters@tm.tue.nl (G. Duysters).
} 
uncertainty can be roughly divided into two groups: exogenous uncertainty, which is unaffected by firm's actions, and endogenous uncertainty, which is embedded in the relationship and can be reduced by actions of the firm.

When the environment is turbulent, innovating firms attach more value in keeping their options open. In addition, when an innovating firm intends to source nascent technologies, uncertainty about the future business potential of the technology is very high. Hence, under conditions of exogenous uncertainty, firms will prefer to maximize flexibility and prefer to make small (learning) investments, which facilitate reversibility of actions in combination with low degrees of financial commitments.

Uncertainty may also exist within a technology sourcing relationship. For instance, when two partners have a relatively small technological overlap (i.e. when the technological distance is high) it might be difficult for the investing firm to recognize and absorb its partner's technological capabilities. On the one hand, this might lead to a preference for more integrated modes which require a higher level of integration in order to increase the efficiency of the transfer and accumulation of knowledge. On the other hand, the greater the dissimilarities in the knowledge bases, the longer it will take before uncertainty about the opportunity has resolved, making a higher level of commitment less attractive. Another indicator for endogenous uncertainty is the existence of prior cooperation between the partners. Prior cooperation can be used to overcome information asymmetry among partners, which occurs when they do not have access to all the relevant information to make an investment decision. Therefore, we expect that prior cooperation enhances the willingness of companies to enter into a relationship that involves a higher level of commitment. However, one might also argue that prior cooperation enhances the building of trust between partners, thus making a more integrated solution less favorable.

Based on a sample consisting of the largest companies in the pharmaceutical industry, we find that there is no support for an ordinal ranking of the different external sourcing modes as has been suggested many times in the literature. However, depending on the type of uncertainty, we find a clear preference for particular governance modes. Under high levels of environmental turbulence, non-equity technology alliances are clearly the most favorable option. Technological newness has a strong, negative effect on the likelihood of using M\&As and joint ventures instead of nonequity alliances. However, the results also show a clear preference for the use of CVC over non-equity alliances. A larger technological distance between two firms also increases the chance to use CVC investments over non-equity alliances, whereas minority holdings are the least favored option. The strong preference for CVCs to source externally developed technology that is distant from the focal firm's technological core shows the particular role CVCs play in external technology sourcing. Finally, when prior cooperation between firms exists, we find that minority holdings and joint ventures are preferred over non-equity alliances, but we find no differential effect between the use of non-equity alliances and M\&As.

To conclude, the results indicate that the benefits of using a particular type of external technology sourcing mode depend on the type of uncertainty - external and relational - the companies are coping with. This implies that each governance mode has its own strengths and weaknesses to cope with environmental turbulence, emerging technologies, technological distance between partners and technology sourcing in the wake of prior cooperation.

\section{Introduction}

The increasing speed of technological change generates a competitive landscape that is characterized by a high degree of uncertainty (Hitt et al., 2001; Wadhwa and Kotha, 2006). In these uncertain environments, firms feel the pressure to develop new products and services in order to create new business opportunities and to enhance corporate renewal. As a result, corporate entrepreneurship is becoming a more crucial part of the strategic management of the firm (Dess et al., 1997). The activities firms employ when pursuing corporate entrepreneurship have significant resource implications (Teng, 2003). As noted by Stevenson and Jarillo (1990), entrepreneurial firms often undertake corporate entrepreneurship activities regardless of the resources they currently control. Often, this results in significant gaps with regard to financial, physical, or knowledge-based resources. Especially knowledge-based resources are critical in this respect due to their strategic value and often tacit nature. The corporate entrepreneurship activity of firms confronts them with the dual challenge of exploring entrepreneurial opportunities and pursuing the required (knowledge-based) resources simultaneously, under conditions of uncertainty regarding both the opportunity and the resources. As a result, the acquisition of complementary or supplementary knowledge is a major theme in corporate entrepreneurship (Dougherty, 1995; Jones et al., 2001; Tsai and Wang, 2008).

Acquisition of external knowledge is an integral part of acquisitive learning (Dess et al., 2003; Zahra and Bogner, 1999), in which firms acquire and internalize knowledge external to their boundaries (Hitt et al., 2000). There are many 
ways in which firms can acquire external knowledge, each of which reflects different priorities or circumstances of firms. Traditionally, firms have emphasized strategic alliances, joint ventures, license agreements and mergers and acquisitions. More recently, firms have also become aware of other options such as corporate venture capital investments (Allen and Hevert, 2007; Dushnitsky and Lenox, 2005a, 2005b, 2006; Wadhwa and Kotha, 2006) and technology exploration in cooperation with research labs and universities (George et al., 2002). Innovating companies can choose between these external knowledge sourcing modes in order to react in a flexible way to new technological developments and changing market conditions. Although all these sourcing modes are important for firms to consider, prior studies have often limited their attention to one or two governance modes in particular. For instance, some studies have focused on the choice between different types of strategic alliances (Gulati and Singh, 1998; Santoro and McGill, 2005) or between strategic alliances and M\&As (Folta and Leiblein, 1994; Garette and Dussauge, 2000; Hagedoorn and Duysters, 2002; Hoffmann and Schaper-Rinkel, 2001; Lambe and Spekman, 1997; Roberts and Liu, 2001; Vanhaverbeke et al., 2002). Another body of literature has paid attention to the growing importance of corporate venture capital (CVC) as a strategy to acquire new technologies (e.g. Dushnitsky and Lenox, 2005a). Despite the increased emphasis on the use of CVC as a driver for innovative output, in studies on external technology sourcing this organizational mode has not yet been incorporated as an alternative compared to strategic alliances and/or M\&As. Although it is evident that innovating firms choose between a wide spectrum of knowledge sourcing and developing modes, comparing a broader set of sourcing modes has not yet been done in a systematic way. Therefore, to get the full picture of how companies use different modes of external corporate venturing, it is important to address the issue raised here in a more comprehensive way, incorporating corporate venture capital as a distinct strategy. In order to fill this gap, this paper focuses on a wide range of external sourcing modes that can be used to fill knowledge gaps in large, diversified firms. In spite of our focus on this broad array of external technology acquisition modes we will pay particular attention to the effect of exogenous and endogenous uncertainty on the choice between different governance modes for external technology sourcing. Despite the well-recognized importance of uncertainty as a central driver for sourcing decisions, systematic empirical studies on the role of uncertainty in governance mode choices for external venturing have been relatively sparse. In particular, previous studies have not taken into account the impact of different forms of uncertainty on governance mode choice (Mahoney, 1992; Sutcliff and Zaheer, 1998).

Our analysis focuses on the choice between corporate venture capital investments, non-equity alliances, joint ventures, minority holdings, and mergers and acquisitions. Although other sourcing modes exist, these are most important from an external corporate venturing perspective (Keil, 2002; Schildt et al., 2005). In addition, the modes listed here incorporate a full range of options that can be ranked along the continuum between arms-length transactions and a fully integrated solution (Gulati and Singh, 1998; Hagedoorn and Sadowski, 1999; Nielsen, 2002; Santoro and McGill, 2005; Villalonga and McGahan, 2005). In the remainder of this paper the terms less and more integrated governance modes will be used, referring to the continuum discussed here, ranging from non-equity alliances as the less integrated mode of governance respectively followed by CVC investments, minority holdings, joint ventures, and M\&As, the latter being the most integrated governance mode.

The structure of the paper is as follows. First, we will provide a more detailed background to develop some hypotheses on how different types of uncertainty affect the choice for more or less integrated governance modes. Second, we will test the hypotheses using a longitudinal dataset comprising data on inter-organizational relationships of the largest companies in the pharmaceutical industry. This section includes a description of the data, the variables included in the study and the methods used. Next, we present and discuss the results, followed by the conclusions and some suggestions for further research.

By doing so, we aim to contribute to the literature in the following areas. First, we expand the range of mode-types under study, including corporate venture capital as a distinct sourcing strategy. Second, we offer a detailed analysis of the role of uncertainty in government mode choice, focusing in particular on the role of exogenous and endogenous uncertainty. We draw on both transaction cost economics (TCE) and real options theory (RO) to develop our arguments.

\section{Theory and hypotheses}

\subsection{The continuum of governance modes}

Traditionally, organizational theory has distinguished between markets and hierarchies, where firms are regarded as hierarchical entities, interacting with other firms through market transactions (Williamson, 1975). However, as noted by 
Powell (1990), the existing boundaries of firms are blurring as they engage in different types of inter-organizational contracting that falls between arms-length market transactions and vertical integration. These arrangements can take the form of joint ventures, strategic alliances, or other forms of inter-organizational collaboration. Previous studies have argued that these modes of collaboration can be ranked along the continuum between arms-length transactions and a fully integrated solution (Gulati and Singh, 1998; Hagedoorn and Sadowski, 1999; Nielsen, 2002; Santoro and McGill, 2005; Villalonga and McGahan, 2005). For example, Gulati and Singh (1998) distinguish between joint ventures, minority holdings and strategic alliances, ranking joint ventures at the hierarchical end of the continuum, followed respectively by minority holdings and strategic alliances towards the market-transaction end. Santoro and McGill (2005) distinguish and rank a number of alliance governance modes, ranging from licensing at the market end of the continuum, followed by cross-licensing, bilateral alliances, and minority equity alliances, to equity joint ventures at the hierarchy end.

In a similar vein, we argue that the governance modes used in this paper (non-equity technology alliances, CVC investments, minority holdings, joint ventures and M\&As) can also be ranked along the same continuum. Non-equity technology alliances have few hierarchical controls and are hence the most flexible form of cooperation, entailing a relatively low level of control over its partner. Moreover, non-equity alliances represent low levels of irreversible commitment due to the lack of equity involved. As a result, non-equity technology alliances come closest to market transactions. CVC investments and minority holdings, in which the investing company takes a minority share in another firm, are also a flexible form of cooperation, though the level of control is greater than in strategic alliances, partly because of the equity participation. Although both types of investments are in fact minority holdings, a clear distinction between the two exists. CVC investments typically occur in start-up firms and are normally organized in the focal firm by means of the establishment of a separate organizational unit with allocated funds. In addition to that, interaction between the venture and the investing firm usually occurs via the CVC unit (Schildt et al., 2005). Minority holdings, on the other hand, often occur as a means to gain control in a strategic alliance or as a first step towards a merger or acquisition. Hence, it can be argued that in terms of commitment and flexibility, CVC investments are more flexible and involve less commitment and as a result are positioned more towards the arms-length end of the continuum, followed by minority holdings. Joint ventures represent a higher level of integration, due to the increasing involvement of equity and the establishment of a new organizational entity. Finally, M\&As represent the highest level of vertical integration as the partner (or target) company is fully controlled by the investing firm.

\subsection{Exogenous and endogenous uncertainty}

When estimating the effect of uncertainty on the use of different governance modes, it is important to note that uncertainty exists in many forms and that each form may have a different impact on the governance mode choice (Mahoney, 1992; Sutcliff and Zaheer, 1998). Uncertainty affecting governance mode decisions can roughly be divided among two groups: exogenous and endogenous uncertainty (Folta, 1998). Exogenous uncertainty refers to uncertainty that 'is largely unaffected by firm actions' (Folta, 1998: 1011) and largely resolves over time. Exogenous uncertainty might take the form of environmental turbulence, but also technological newness is exogenous to the investing firm. Real options theory mainly deals with exogenous uncertainty, where the value of the option is determined by the uncertainty surrounding the investment. Endogenous uncertainty on the other hand refers to uncertainty that "can be decreased by actions of the firm' (Folta, 1998: 1010). Endogenous uncertainty can often be found as taking the shape of relationship-specific uncertainty when firms are sourcing technologies externally for new business development. This type of uncertainty is typically represented by dissimilarities among partners which can be caused for instance by different knowledge bases or by the lack of prior cooperation to overcome information asymmetries. Both TCE and RO can be applied to decision-making under endogenous uncertainty, since they both stress a different perspective. RO stresses the value that is embedded in the uncertainty about the opportunity and gradually decreases as a result from learning investments. TCE takes on a different perspective in which hierarchy is presented as a way to circumvent the costs that are associated with the writing of contracts under higher levels of uncertainty.

\subsection{Environmental turbulence}

High-technology environments are typically characterized by unpredictable change fostered by radical innovations and therefore entail a rather high level of environmental turbulence. When the environment is turbulent, it becomes more valuable for innovating firms to keep their options open. Hence, they will prefer to maximize flexibility in this 
stage while uncertainty decreases and a possible follow-on investment can be decided upon (Van de Vrande et al., 2006). Therefore, under these circumstances, innovating firms will typically choose for less integrated governance modes with a lower level of financial commitment to reduce the potential costs associated with environmental turbulence in general and technology changes in particular (Sutcliffe and Zaheer, 1998). Not only can these types of investment be reversed more easily once outcomes are not satisfying, they also allow the investing company to bet on more than one horse at the same time. By investing simultaneously in different arrays of (competing) technology, the firm reduces the risk of being locked in a limited few (Moon, 1998). Moreover, such a strategy enhances the firm's ability to respond quickly to changing environments.

Previous research has indicated the preference among companies facing turbulent or uncertain environments to favor flexibility over control. In support of this, Hagedoorn and Duysters (2002) find that industries that are characterized by rapid technological change ask for flexible forms of organization that enable quick strategic response. In their analysis, they find firms to favor alliances over of M\&As. Following RO arguments, Folta (1998) and Moon (1998) found that technological turbulence leads to a preference for equity collaborations over acquisitions, whereas Santoro and McGill (2005) show how the dynamism of the technological subfield of an alliance negatively affects the use of more hierarchical alliance forms. Their findings suggest that under conditions of environmental turbulence firms are more likely to prefer non-equity alliances over minority holdings and minority holdings over joint ventures. Balakrishnan and Wernerfelt (1986), furthermore, show how integration is negatively affected by the frequency of technological change, an effect that holds specifically if the degree of competition is high. This view to delay financial commitment when uncertainty is high is also confirmed in studies investigating entrepreneurial entry (O'Brien et al., 2003) and partner buyouts (Folta and Miller, 2002).

To sum up, environmental turbulence seems to be a forceful driver to delay commitment and to keep different investment options open. The flexibility generated by real options allows firms to cope with unforeseen contingencies and facilitates reversibility of actions in combination with low degrees of financial commitments. Hence, we hypothesize that when environmental turbulence is high, companies are more likely to use less integrated governance modes that are more flexible, and involve a lower level of commitment.

Hypothesis 1. Environmental turbulence has a negative effect on the use of more integrated governance modes.

\subsection{Technological newness}

Another important source of uncertainty within new business development projects is the uncertain business potential of the product or technology the firm invests in. Uncertainty with respect to the technological characteristics and market feasibility of products or technologies cannot easily be reduced by the investing firm, but typically decreases over time as the technology matures and the innovating firm gets a better understanding of the technology and its market potential thanks to subsequent R\&D or learning investments. When a technology is in an early stage of development, its basic concepts stem from practice, thereby raising the uncertainties associated with it (Ahuja and Lampert, 2001). Additionally, the possible success of the innovation is more uncertain in nascent technologies (Sahal, 1985). Hence, the high uncertainty surrounding new technologies makes it more valuable for the investing firm to make small, initial investments reducing the uncertainty about the business opportunity. Those early (and small) investments can be regarded to as learning investments (Janney and Dess, 2004) and intent to bring down the uncertainty through technological and market feasibility studies. Therefore, when the technology of the partner is rather new, companies will be more likely to pursue agreements that are more towards the market-transaction end of the continuum, such as strategic alliances and corporate venture capital investments, in order to remain flexible (Vanhaverbeke et al., 2002).

Previous studies have also pointed to the use of less integrated governance modes under conditions of technological newness. Pisano (1990), for instance, found that in the early days of biotechnology, technological uncertainty has played a critical role in established firms' decision to acquire biotechnology R\&D from the outside. In addition to that, Lambe and Spekman (1997) argue that in the early stages of the technology life cycle where industry uncertainty is high, alliances take precedence over the two other options (make and buy) for acquiring new technology. Moreover, Steensma and Fairbank (1999) find that under conditions of high uncertainty (with respect to technological and commercial success), arms-length arrangements such as licensing are more likely to being pursued than joint development or acquisitions.

To sum up, when the technology of the partner firm is rather new and hence its success is unpredictable, it becomes more valuable for the investing firm to make small, learning investments. Therefore, we hypothesize that in the case of 
technological newness, the investing firm will be more likely to use less integrated governance modes that are highly reversible and involve a lower level of commitment.

Hypothesis 2. Technological newness has a negative effect on the use of more integrated governance modes.

\subsection{Technological distance}

Dissimilarities between the knowledge bases of two partners might have an effect on the choice of the governance mode to shape their cooperation. Larger dissimilarities lead to two types of problems; the first one is related to limited capability to detect, assimilate and integrate technology that is quite different from a firms' core technologies. Next, larger technological distance between two partners may also lead to relational uncertainty forcing them to safeguard against opportunistic behavior of the other.

The first type of problem is typically related to the absorptive capacity of firms. The more dissimilar the knowledge bases of two partners, the larger the probability that the absorptive capacity of the investing firm falls short, affecting the extent to which a firm can recognize and absorb its partner's technological capabilities (Cohen and Levinthal, 1990; Lane \& Lubatkin, 1998). One can argue that partnering firms will choose governance modes that are more integrated in order to facilitate the effective transfer of distant knowledge (Cantwell \& Colombo, 2000; Gulati \& Singh, 1998; Mowery et al., 1996; Sampson, 2004). For instance, Colombo (2003) finds support for the hypothesis that divergence in partner's technological specialization increases the propensity to use equity alliances over non-equity alliances.

Second, larger technological distance between the partners and its associated absorptive capacity problems also leads to endogenous or relational uncertainty, i.e. the uncertainty within the technology sourcing relationship or the uncertainty between the partners which is typical for the TCE approach (Williamson, 1975, 1985). ${ }^{1}$ Large technological distance between two partners might lead to adverse selection. When the technological distance between the partners is high, information asymmetries emerge, which might result in the selection of inferior technologies. It can be argued that in order to overcome the danger of adverse selection, a higher level of integration is favorable to cope with information asymmetries and to protect the investment against opportunistic behavior from its partner. Moreover, higher levels of technological distance between partners imply higher levels of uncertainty, which makes it more costly and more complicated to write complete contracts. As a result, a higher level of integration becomes a more attractive alternative (Williamson, 1975).

To sum up, when the knowledge bases of the firms involved in a technology sourcing partnership are dissimilar, a higher level of integration is necessary to increase the efficient transfer and accumulation of knowledge. Moreover, dissimilar knowledge bases increase the danger of adverse selection and make it more difficult to write contracts, hence making a higher level of integration more favorable. As a measure for dissimilarity among technological competences, we use technological distance between the firms. We hypothesize that when technological distance is high, companies will use more integrated governance modes entailing a higher level of hierarchical control.

Hypothesis 3a. Technological distance between the focal firm and its partner has a positive effect on the use of more integrated governance modes.

On the other hand, the greater the knowledge base dissimilarities, the longer it will take before the uncertainty about the opportunity will be resolved, making a higher level of commitment less attractive. Instead, it is better to first build familiarity through small, educational investments or through alliances or joint ventures (Roberts and Berry, 1985). In this way, the investing company creates an option while learning about the opportunity ahead (Van de Vrande et al., 2006). When the knowledge bases are more converged, a higher level of integration becomes more attractive. In addition, Nooteboom (2004) argues that exploration requires a loosening of linkages with large cognitive distance, whereas exploitation should be conducted through more integration and small cognitive distance, hence stressing the likelihood of combining large technological distance with less integration and vice versa. Moreover, opportunistic behavior is not a real threat as long as the business potential of the technology is not

\footnotetext{
${ }^{1}$ According to TCE logic, three types of problems typically arise during the transaction: adverse selection, moral hazard, and hold-up. In this section, we limit our attention to the danger of adverse selection, since adverse selection is typically an issue that might result from technological distance. Moral hazard and hold-up on the other hand are more related to the transaction and the threat of opportunistic behavior in general and will be discussed in relation to prior cooperation.
} 
crystallized into a viable business model. In other words, firms that are not yet familiar with the technological capabilities of its partners will first have to learn from each other before being able to accumulate the knowledge. Thus, greater technological distance makes unintended spill-over of knowledge less likely, decreasing the threat of opportunistic behavior (Colombo, 2003).

Supporting this view, Folta (1998) finds that in case of dissimilar business operations between partners, minority investments are preferred over joint ventures, and that in general equity collaboration is preferred over acquisitions. Moreover, Villalonga and McGahan (2005) come to the conclusion that the relatedness between the focal firm and its partner is associated with the choice of acquisitions over alliances and alliances over divestures. Hagedoorn and Duysters (2002) furthermore find support for their hypothesis that M\&As are more likely when the external source of innovative capability is related to the company's core business (thus, when technological distance is small), and that strategic alliances are more likely for non-core businesses. In addition to that, Vassolo et al. (2004) find that lower technological distance enhances the likelihood of that an alliance partner is being acquired.

In sum, when the partnering firms have dissimilar knowledge bases, the need for learning and flexibility prevails over the need for administrative control. Technological distance between the firms is used as a measure for dissimilarity of technological competences between the partners. When technological distance is high we expect that companies will use less integrated governance modes to increase learning effects that might result from the relationship. Moreover, the use of less integrated governance modes enables those same firms to reverse their commitments at lower sunk costs at any point in time. Therefore, we hypothesize an alternative to Hypothesis $3 \mathrm{a}$ : technological distance has a positive effect on the use of more flexible governance modes that involve a lower level of commitment, and hence are less integrated.

Hypothesis 3b. Technological distance between the focal firm and its partner has a negative effect on the use of more integrated governance modes.

\subsection{Prior cooperation}

In the case of new business development, technology sourcing partnerships often take multiple forms over time. As new technologies are developed and commercialized, subsequent inter-organizational transactions should be in line with the decreasing external uncertainty and the need to increase the level of commitment. As a result, different governance modes will be preferred as an innovation proceeds through the development and commercialization stages.

As discussed above, technological distance between the innovating firm and its partners is an important indicator of endogenous uncertainty. Another important indicator for endogenous uncertainty is the existence of prior cooperation between the partners. Prior cooperation can be used to overcome information asymmetry among partners (Reuer and Koza, 2000; Vanhaverbeke et al., 2002; Williamson, 1985). Information asymmetry occurs when firms do not have access to all the relevant information to make an investment decision. As mentioned before, the uncertainty within the technology partnership might be decreased by using small, initial investments to learn about the partner and its technology. This facilitates more familiarity with the technologies and practices of the partner firm. Real options reasoning suggests that under circumstances of uncertainty, these initial investments are also a way to put off commitment until the potential of the opportunity has become more tangible. If we extend this logic to the choice between different governance modes given prior cooperation, this leads to the suggestion that the inter-organizational transaction entails a higher level of commitment.

This point of view is supported by Duysters and De Man (2003) in their concept of transitory alliances, which are flexible alliance forms that might be intensified and become a more traditional alliance when the opportunity seems promising. Furthermore, Garette and Dussauge (2000) draw attention to the fact that scale alliances might be the first step towards a merger. Some empirical evidence stresses this perspective, arguing that prior cooperation is an effective way to overcome information asymmetries that might exist among partners in a technology sourcing relationship. Balakrishnan and Koza (1993) argue that when information asymmetries exist, joint ventures are preferred over acquisitions, because information asymmetry strongly increases the costs of valuing the target. Vanhaverbeke et al. (2002) found empirical evidence for this argument, suggesting that as soon as the information asymmetry has been resolved as a result from the interaction within the alliance, a firm will move from a strategic alliance to an acquisition. Additionally, Kogut (1991) describes how joint ventures may be acquired later on. Following the arguments presented above, we expect that prior cooperation enhances the willingness of companies to enter into a relationship that is less reversible and that involves a higher level of commitment. Or, alternatively, if there 
is no prior cooperation we expect companies to opt for a governance mode that is less integrated and hence easier to reverse. We therefore hypothesize:

Hypothesis 4a. Prior cooperation has a positive effect on the use of more integrated governance modes.

On the other hand, there is also a body of literature suggesting the opposite. Endogenous problems such as moral hazard and hold-up can be reduced through prior cooperation. Moral hazard refers to the threat of opportunistic behavior which occurs under circumstances of tacit knowledge. Prior cooperation is one way to learn about that knowledge and reduces the threat of opportunistic behavior. The problem of opportunistic behavior in contractual relations that require transaction specific investments - referred to as hold-up - can also be mitigated by prior and thus recurrent cooperation. In fact, more prior cooperation creates trust, which in turn reduces the fear for opportunistic behavior, thereby decreasing the need for control. Gulati (1995) found empirical evidence supporting this view. In his study about the choice among different governance structures for alliances, he finds evidence that prior ties between the partners reduces the likelihood that the next alliance between them will be equity based. Moreover, Reuer et al. (2006) show that trust leads firms to use non-equity alliances over equity alliances, whereas Villalonga and McGahan (2005) find support for the hypothesis that prior alliances positively affect the choice for alliances over acquisitions. In addition to that, Santoro and McGill (2005) found that the lack of prior ties induces companies to use more hierarchical governance modes. The results of their ordinal logit analysis suggest that partner uncertainty leads firms to prefer joint ventures over minority holdings, and minority holdings over non-equity alliances. Gulati and Singh (1998) furthermore found that repeated ties are more likely to be organized as non-equity alliances instead of minority holdings, which in turn are preferred over joint ventures. Also Ring and Van der Ven (1994) have shown that trust is an essential condition for market transactions. If we extent this view to the broader spectrum of inter-organizational relationships, it can be argued that prior cooperation allows the investing company to use governance modes that involve a lower level of commitment. Consequently, we propose an alternative hypothesis:

Hypothesis $4 \mathrm{~b}$. Prior cooperation has a negative effect on the use of more integrated governance modes.

\section{Methods}

\subsection{Data and sample}

To test the hypotheses, we use a sample consisting of all corporate venture capital investments, non-equity technology alliances, equity alliances, and mergers and acquisitions completed between 1990 and 2000 by the 153 largest companies that were active in the pharmaceutical industry during the observation period. The dataset is crosssectional and comprises 1,810 deals: 783 of these deals are technology alliances, 129 corporate venture capital investments, 206 minority holdings, 125 joint ventures, and 567 mergers and acquisitions.

The dataset was constructed in the following way. First, we have selected the largest companies in the pharmaceutical industry between 1990 and 2000. We focused on the largest companies in the industry in order to have a consistent set of firms over that observation period. Moreover, small (or privately held) firms do not disclose the relevant information. Prior research on alliances and acquisitions has for that reason also been focused on the largest companies in the industry (Ahuja, 2000; Gulati, 1995; Gulati and Garguilo, 1999; Hitt et al., 1991, 1996). The firms were selected based on their prior patents in the industry. For each year of the observation period, the 200 companies with the largest cumulative number of patents in the industry were collected. Selection was based on patents filed in the following patent classes: $424,435,436,514,530,536,800$, and 930. After selecting the companies with the largest cumulative number of patents in the relevant patent classes, research institutes and universities were removed from the sample. Next, the remaining sample was manually checked for parents and affiliates using Dun \& Bradstreet's Who Owns Whom, which were then aggregated on parent company level. After checking for duplicates, this leads to 153 independent companies to be included in the sample. We will refer to these independent companies as "focal firms", to distinguish them from their partners.

Next, we have gathered for these firms all the venture capital investments, technology alliances, minority holdings, joint ventures, and merger and acquisition activity during the period 1985-2000, as well as patent data and financial information. Corporate venture capital data were derived from the Thomson VentureXpert database, data concerning 


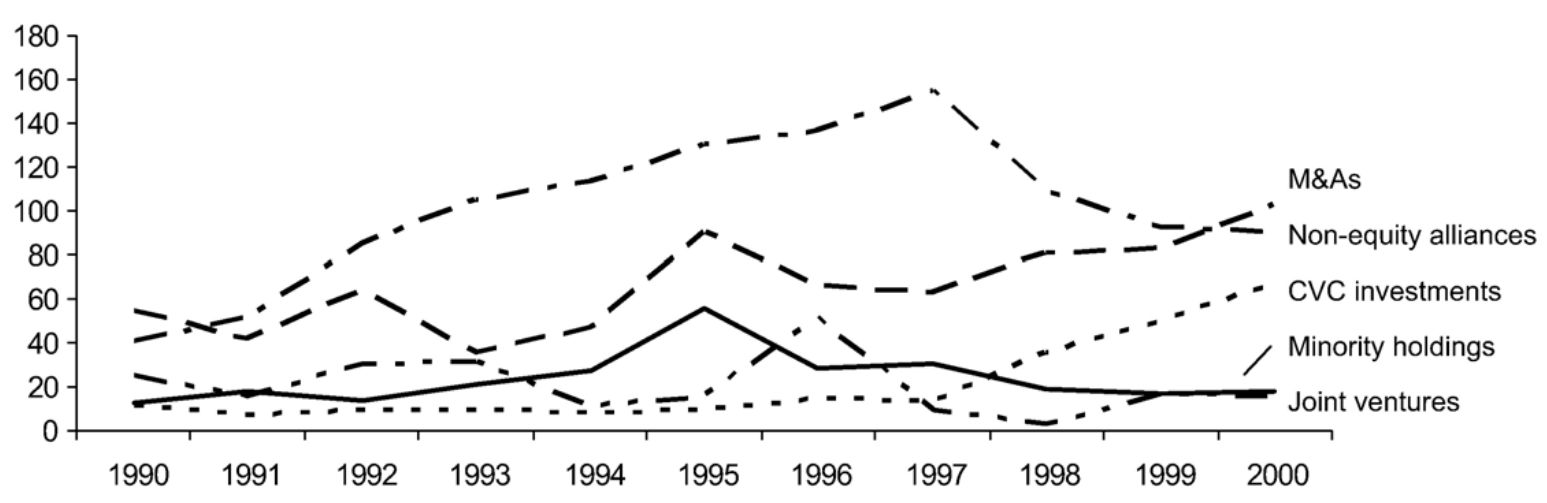

Fig. 1. Evolution of governance modes over time (1990-2000).

alliances and joint ventures were obtained from the MERIT-CATI databank on Cooperative Agreements and Technology Indicators (Hagedoorn, 1993), and we used Thomson ONE Banker to collect information regarding the companies' M\&A activity. Because the collected alliances and corporate venture capital investments have a strong technology component, we included only technological M\&As in the sample, following the method proposed by Ahuja and Katila (2001). ${ }^{2}$

MERIT-CATI distinguishes 22 types of inter-organizational relationships, including joint ventures and minority holdings. Thomson ONE Banker also includes joint ventures and minority equity investments. Thus, it might occur that one deal is reported more than once, due to the merger of different data sources containing the same information. Therefore, all entries were checked for duplicates (i.e. same firms, same type of investment, but different source), which were then removed from the sample. In the case of duplicates among minority holdings and CVC investments, minority holdings were removed. After all, every CVC investment is also a minority holding, but not every minority holding can be regarded as a CVC investment. We therefore follow CVC investments as reported in VentureXpert.

Financial data were gathered using Worldscope, including sales, research and development expenses and number of employees. In addition to that, we collected patent information for all firms included in the sample using data from the US Patent and Trademark Office. Because the US Patent and Trademark Office grants patents both on subsidiary as well as on parent company level (Patel \& Pavitt, 1997), and the organizational level on which patents are applied for differs between companies, the patents were manually consolidated on parent company level for each observation year, using Who Owns Whom by Dun \& Bradstreet. Fig. 1 shows the temporal evolution of the different governance modes used in this study.

\subsection{Dependent variable}

Because we want to predict the effect of different types of uncertainty on governance mode choice, the dependent variable indicates the type of inter-organizational agreement that was entered to source external technology. The different sourcing modes are non-equity technology alliances, CVC investments, minority holdings, joint ventures and M\&As. As argued before, these modes incorporate a full range of options that can be ranked along the continuum between arms-length arrangements and full integration (Williamson, 1985; Powell, 1990; Powell and DiMaggio, 1991). Non-equity technology alliances are defined as 'cooperative efforts in which two or more separate organizations, while maintaining their own corporate identities, join forces to share reciprocal inputs' (Vanhaverbeke et al., 2002). Strategic alliances come closest to market transactions and are hence the most flexible form of cooperation, entailing a relatively low level of control over its partner. CVC investments and minority holdings, in which the investing company takes a minority share in another firm, are also a flexible form of cooperation, though the level of control is greater than in strategic alliances, partly because of the equity participation. CVC investments can be defined as 'equity investments by established corporations in entrepreneurial ventures' (Dushnitsky and Lenox, 2006), whereas minority holdings are regarded as 'partnership in which one of the firms takes a less than $50 \%$ equity position in the other firm.' Joint ventures represent a higher level of integration, due to the increasing involvement of equity and require the formation of a new

\footnotetext{
${ }^{2}$ The method employed in this paper is slightly different from the method by Ahuja and Katila (2001). Ahuja and Katila (2001) included also deals for which they found press releases indicating technology as a specific motivation for undertaking the M\&A. Since we had no access to these press releases, we could only include deals in which the partner has applied for at least one patent.
} 
organizational entity by the partners. M\&As represent the highest level of hierarchy and are defined as 'cumulative ownership of $50 \%$ or more of a partner firm' (Folta, 1998). The different modes are labeled according to their supposed level of integration, which allows us to perform an ordinal logistic regression. Non-equity technology alliances, being closest to arms-length transactions, are coded 1, followed respectively by CVC investments (2), minority holdings (3), joint ventures (4) and M\&As (5), being the mostly integrated governance mode.

\subsection{Independent variables}

Following the hypotheses, independent variables include environmental turbulence, technological newness, the technological distance between the investing firm and the partnering or target firm and prior cooperation between them. The independent variables environmental turbulence, technological newness, and technological distance, as well as the control variable technological capital, are calculated using patent data as an indicator for technological knowledge. Prior research has pointed towards the fact that technological knowledge depreciates sharply over time (e.g. Grilliches, 1979), losing most of its value within five years. Therefore, a five year moving window is used to calculate most of our variables. Other studies using patent data as an indicator for technological knowledge have for that reason also used five years moving windows (e.g. Katila and Ahuja, 2002; Stuart, 2000).

Environmental turbulence refers to the technological change over time. The measurement is based on patent classes that are relevant for the pharmaceutical companies in our sample. To determine the relevant technological fields, we took the $80 \%$ most important patent classes based on the patent applications of the focal firms during the observation period. Because our sample firms are largely diversified, $80 \%$ is taken rather than $100 \%$ in order to overcome too much noise in the calculation of this variable. Next, for these patent classes, we calculated for each year the number of patent applications worldwide. ${ }^{3}$ To determine the similarities of the patent distributions of two subsequent observation years, we calculated the Pearson correlation coefficient $\rho$. Technological turbulence is then calculated as $1-\rho$, so that higher values indicate higher levels of technological turbulence. This variable is lagged one year.

Technological newness is a firm-level variable, which is developed in a two-step process. First, we determine the age of all patent classes. This is calculated as the median of the age ${ }^{4}$ of all patents in a patent class in a particular year. To overcome outlier bias, we use the median age rather than the average to calculate the age. Second, to calculate the average technological age per firm, we multiply the share of patent applications by the technology age for each patent class. Technological newness is then calculated as $-1 *$ technology age, such that higher values represent a higher level of technological newness.

Technological distance refers to the (lack of) overlap between the knowledge base of the investing company and the knowledge that is acquired externally. We use the method developed by Jaffe (1986) to calculate the technological proximity between two firms $\left({ }_{i}\right.$ and ${ }_{j}$ ). Following this method, the technological proximity between two firms is computed as the uncentered correlation between their respective vectors of technological capital (measured as the cumulative patent applications in technology class $k$ over the five years prior to the investment), Pik and P $j k$ respectively:

$$
T i j=\frac{\sum_{k} P_{i k} P_{j k}}{\sqrt{\sum k P_{i k}^{2} \sum k P_{j k}^{2}}}
$$

The technological proximity $\left(T_{i j}\right)$ measure takes a value between 0 and 1 according to their common technological interests. To calculate technological distance, this variable is transformed into a new one, which equals $1-T_{i j}$.

The variable prior cooperation is a count variable, indicating the number of previous cooperation efforts between the focal firm and the partner firm in the five years prior to the observation year (Gulati, 1995).

\subsection{Control variables}

The decision to enter a specific technology sourcing mode can also be affected by factors, other than environmental and relation specific uncertainty. We therefore included a number of control variables to capture firm-specific characteristics.

\footnotetext{
${ }^{3}$ We use all patent applications in a particular year rather than only the patents of the focal firms. Hence, this variable is not dependent on the firm sample.

${ }^{4}$ The age of the patent is the time elapsed between the application year and the year of observation.
} 
Prior experience with particular governance modes might lead to the development of certain capabilities that enhance the effectiveness of managing these governance modes (Rothaermel and Deeds, 2006). As a result, prior experience might result in the preference of a particular governance modes over others (e.g. Hagedoorn and Duysters, 2002; Villalonga and McGahan, 2005). Therefore, we included the control variable experience, indicating the firm's experience with respect to particular modes of technology sourcing in the five years prior to the investment under study. Furthermore, we added technological capital to measure the firm's technological strength (Vanhaverbeke et al., 2002). This variable is computed as the cumulative number of patents applied for by the focal firm in the five years prior to the investment under study.

Furthermore, we controlled for size (natural logarithm of sales) and $R \& D$ expenditures as a percentage of sales. Both variables are lagged by one year. Finally, we introduced dummy variables to capture industry and country specific effects. The yearly dummy variables capture eventual changes in preference for particular governance modes. In this way we can control for instance for the booming venture capital markets, the increasing popularity of corporate venture capital or other developments in the environment.

\subsection{Methods}

The dataset used is set up as a cross-sectional database where each record represents an inter-organizational relationship of any of the types. In this analysis, it is appropriate to use an ordered logit model to estimate the effect of uncertainty on the choice between less and more integrated governance modes. Ordered logistic regressions control for the ordered nature of the dependent variable. Following the literature (Williamson, 1985; Powell, 1990; Powell and DiMaggio, 1991), we argue that the dependent variable can be ranked along a continuum from less to more integration: non-equity, technology alliances being the most arms-length relationship, moving to CVC investments, which are still highly flexible though more integrated as a result of their equity component, followed respectively by minority holdings, joint ventures and mergers and acquisitions on the other end of the continuum representing the highest level of integration in the company. Although the first results of this estimation procedure seemed to be in line with the hypothesized signs, it must be noted that in the ordinal logit model the parallel regression assumption, which assumes that the relationship between each pair of outcome groups is the same, should hold. The parallel regression assumption was tested using the Wald test by Brant (1990), showing that this assumption was violated for most of the independent variables. ${ }^{5}$ As a result, the ordinal logit model was rejected. Although according to Long and Freese (2003) the parallel regression assumption is often violated, the results for our model imply that ranking the different modes for technology sourcing along a continuum from less to more integration, is more complicated than literature suggests. ${ }^{6}$

Since the ordinal logistic regression model, is rejected, we replaced it by a multinomial logit model. This model does not take into account any order in the dependent variable and is therefore an interesting mechanism to test the hypotheses. Since there is no predetermined ordering, the results of the multinomial logit can provide a more detailed insight in when particular governance modes are preferred over other, depending on the circumstances.

\section{Results}

Table 1 presents the descriptive statistics and correlations for all variables.

The results of the multinomial logit estimates are presented in Table 2. ${ }^{7}$ Both models show the estimates of the choice of corporate venture capital investments (CVC), minority holdings (MH), joint ventures (JV) and mergers and acquisitions (M\&A) over the default category of non-equity alliances. Model 1 includes the results for the control variables only, whereas Model 2 also incorporates the independent variables. Some of the high correlations between some of the independent variables in Table 1 indicate possible multi-collinearity problems. We therefore estimated different models, excluding some of the variables with high correlations from the analyses. The results are very similar to the ones presented in Table 2, indicating that these results are robust.

\footnotetext{
${ }^{5}$ Results of the ordinal logit analysis and the Brant test are available from the author upon request.

${ }^{6}$ We will get back to the implications of these results in the discussion section.

${ }^{7}$ An underlying assumption in the multinomial logit model is the independence of irrelevant alternatives (IIA). We used the Hausman and McFadden (1984) test to check if the null hypotheses ((H0: Outcome-J vs Outcome-K) are independent of other alternatives) could be rejected and found that the IIA assumption has not been violated.
} 
Table 1

Descriptive statistics

\begin{tabular}{|c|c|c|c|c|c|c|c|c|c|c|c|c|c|c|c|}
\hline & Mean & Std. dev. & 1 & 2 & 3 & 4 & 5 & 6 & 7 & 8 & 9 & 10 & 11 & 12 & 13 \\
\hline Alliance experience & 8.09 & 7.55 & & & & & & & & & & & & & \\
\hline CVC experience & 1.70 & 5.27 & 0.18 & & & & & & & & & & & & \\
\hline $\begin{array}{l}\text { Minority holding } \\
\text { experience }\end{array}$ & 2.01 & 2.15 & 0.43 & 0.30 & & & & & & & & & & & \\
\hline $\begin{array}{l}\text { Joint venture } \\
\text { experience }\end{array}$ & 1.57 & 2.37 & 0.58 & 0.02 & 0.06 & & & & & & & & & & \\
\hline M\&A experience & 4.44 & 3.85 & 0.38 & 0.42 & 0.29 & 0.37 & & & & & & & & & \\
\hline $\mathrm{R} \& \mathrm{D}$ to sales & 0.08 & 0.09 & -0.05 & -0.01 & 0.13 & -0.22 & -0.19 & & & & & & & & \\
\hline Size & 9.45 & 1.43 & 0.08 & 0.07 & 0.04 & 0.13 & 0.12 & -0.40 & & & & & & & \\
\hline Dummy Europe & 0.39 & 0.49 & 0.08 & -0.18 & -0.09 & 0.13 & 0.15 & -0.09 & 0.03 & & & & & & \\
\hline Dummy Japan & 0.05 & 0.22 & -0.22 & -0.07 & -0.18 & -0.11 & -0.23 & -0.06 & 0.55 & -0.18 & & & & & \\
\hline Dummy pharma & 0.52 & 0.50 & 0.02 & 0.12 & 0.21 & -0.33 & -0.07 & 0.45 & -0.01 & 0.07 & -0.02 & & & & \\
\hline $\begin{array}{l}\text { Environmental } \\
\text { turbulence }\end{array}$ & 1.60 & 1.41 & -0.06 & -0.12 & 0.03 & -0.11 & -0.04 & 0.01 & 0.00 & 0.01 & 0.00 & 0.07 & & & \\
\hline $\begin{array}{l}\text { Technological } \\
\text { newness }\end{array}$ & -10.43 & 3.29 & 0.00 & 0.15 & 0.18 & -0.15 & -0.06 & 0.24 & -0.08 & -0.16 & -0.01 & 0.29 & 0.02 & & \\
\hline $\begin{array}{l}\text { Technological } \\
\text { distance }\end{array}$ & 0.69 & 0.28 & 0.07 & 0.02 & -0.10 & 0.18 & 0.13 & -0.21 & 0.04 & 0.04 & -0.05 & -0.22 & -0.07 & -0.19 & \\
\hline Prior cooperation & 0.20 & 0.61 & 0.16 & 0.11 & 0.13 & 0.14 & 0.16 & -0.01 & 0.00 & -0.01 & -0.05 & 0.01 & 0.00 & 0.01 & -0.04 \\
\hline
\end{tabular}

Year dummy variables not included in the table; the highest correlation is 0.36 between year 2000 and CVC experience.

Table 2 only shows the estimates for each category against the default category (non-equity alliances). To check whether there is still a differential effect of the independent variables on the different governance modes, we can use the odds ratios presented in Table 3. This table decomposes the effect of the independent variables on the governance mode choice into binary choice models. Each binary choice is represented in a different column, where values greater than 1 indicate a significant effect in the hypothesized direction, and a value smaller than 1 indicates a significant effect in the opposite direction. Non-significant results are not included.

The results in Table 2 partially support the hypotheses. Environmental turbulence is expected to have a positive effect on the use of less integrated governance modes (Hypothesis 1). The results in Table 2 indicate that environmental uncertainty has a negative effect on the choice of CVC investments, minority holdings, joint ventures and M\&As over non-equity alliances. The odds ratios in Table 3 furthermore show that the environmental turbulence also negatively affects the choice of joint ventures over CVC investments, minority holdings and M\&As, and that of M\&As over minority holdings. Clearly, under high levels of environmental turbulence, non-equity technology alliances are the most favorable option. CVC investments, minority holdings and M\&As are favored over joint ventures, and minority holdings are preferred over M\&As, but the data show no significant differential effect of environmental turbulence on the preference for CVC investments over minority holdings or M\&As. As a result, the first hypothesis is partly supported by the data, as strategic alliances are the most favorable option, but we did not find a linear ranking from less to more integrated governance modes.

The second hypothesis, predicting that technological newness of the partner's technology has a positive effect on the use of less integrated governance modes, is partially supported by the results. The results presented in Table 2 show that technological newness has indeed a strong, negative effect on the likelihood of using M\&As and joint ventures instead of non-equity alliances. However, the results also imply that when the technology is new, CVC investments are preferred over non-equity alliances and minority holdings, which in turn are preferred over joint ventures and M\&As. Thus, contrary to our expectations, technological newness leads only to some extent to the use of less integrated governance modes: while M\&As and joint ventures become less attractive, there is a clear preference for the companies in this study to choose CVC investments over all other governance modes. This result shows that the uncertainty related to the newness of partners' technology is considered by the focal firms as different from technological turbulence. When technological turbulence is high, alliances are preferred over CVC investments, and the reverse holds in case the partners' technology is new.

Hypothesis 3a predicts that technological distance between partnering firms requires more integrated governance modes. The opposite was proposed by Hypotheses $3 \mathrm{~b}$. The results in Table 2 partially corroborate Hypothesis $3 \mathrm{a}$, since 
Table 2

Multinomial logit estimates

\begin{tabular}{|c|c|c|c|c|c|c|c|c|}
\hline & \multicolumn{4}{|l|}{ Model 1} & \multicolumn{4}{|l|}{ Model 2} \\
\hline & $\mathrm{CVC}$ & $\mathrm{MH}$ & JV & $\mathrm{M} \& \mathrm{~A}$ & $\mathrm{CVC}$ & $\mathrm{MH}$ & $\mathrm{JV}$ & $\mathrm{M} \& \mathrm{~A}$ \\
\hline Constant & $\begin{array}{c}-2.614 * * \\
(1.292)\end{array}$ & $\begin{array}{c}-1.805 * * \\
(0.829)\end{array}$ & $\begin{array}{c}0.351 \\
(0.974)\end{array}$ & $\begin{array}{l}2.154 * * * \\
(0.673)\end{array}$ & $\begin{array}{c}-3.570 * * \\
(1.476)\end{array}$ & $\begin{array}{c}-1.684 * \\
(0.928)\end{array}$ & $\begin{array}{c}-1.492 \\
(1.056)\end{array}$ & $\begin{array}{c}0.748 \\
(0.736)\end{array}$ \\
\hline Alliance experience & $\begin{array}{c}-0.069^{* * *} \\
(0.026)\end{array}$ & $\begin{array}{c}-0.069 * * * \\
(0.019)\end{array}$ & $\begin{array}{c}-0.005 \\
(0.017)\end{array}$ & $\begin{array}{c}-0.062 * * * \\
(0.012)\end{array}$ & $\begin{array}{c}-0.077 * * * \\
(0.027)\end{array}$ & $\begin{array}{c}-0.070 * * * \\
(0.019)\end{array}$ & $\begin{array}{c}-0.012 \\
(0.017)\end{array}$ & $\begin{array}{c}-0.066^{* * *} \\
(0.012)\end{array}$ \\
\hline CVC experience & $\begin{array}{l}0.182 * * * \\
(0.048)\end{array}$ & $\begin{array}{c}-0.092 * \\
(0.053)\end{array}$ & $\begin{array}{c}-0.096 \\
(0.059)\end{array}$ & $\begin{array}{c}0.063 * \\
(0.036)\end{array}$ & $\begin{array}{l}0.183 * * * \\
(0.049)\end{array}$ & $\begin{array}{c}-0.090 * \\
(0.053)\end{array}$ & $\begin{array}{c}-0.088 \\
(0.058)\end{array}$ & $\begin{array}{c}0.073 * \\
(0.038)\end{array}$ \\
\hline Minority holding experience & $\begin{array}{c}0.106 \\
(0.069)\end{array}$ & $\begin{array}{c}0.037 \\
(0.047)\end{array}$ & $\begin{array}{c}-0.082 \\
(0.065)\end{array}$ & $\begin{array}{c}-0.042 \\
(0.036)\end{array}$ & $\begin{array}{c}0.121 \\
(0.075)\end{array}$ & $\begin{array}{c}0.012 \\
(0.048)\end{array}$ & $\begin{array}{c}-0.059 \\
(0.067)\end{array}$ & $\begin{array}{c}-0.022 \\
(0.036)\end{array}$ \\
\hline Joint venture experience & $\begin{array}{c}-0.088 \\
(0.085)\end{array}$ & $\begin{array}{c}-0.022 \\
(0.058)\end{array}$ & $\begin{array}{c}-0.027 \\
(0.057)\end{array}$ & $\begin{array}{c}0.015 \\
(0.039)\end{array}$ & $\begin{array}{c}-0.089 \\
(0.087)\end{array}$ & $\begin{array}{c}-0.032 \\
(0.059)\end{array}$ & $\begin{array}{c}-0.044 \\
(0.057)\end{array}$ & $\begin{array}{c}0.007 \\
(0.040)\end{array}$ \\
\hline M\&A experience & $\begin{array}{c}0.026 \\
(0.040)\end{array}$ & $\begin{array}{c}0.019 \\
(0.031)\end{array}$ & $\begin{array}{c}0.050 \\
(0.034)\end{array}$ & $\begin{array}{l}0.069 * * * \\
(0.021)\end{array}$ & $\begin{array}{c}0.008 \\
(0.041)\end{array}$ & $\begin{array}{c}0.013 \\
(0.032)\end{array}$ & $\begin{array}{c}0.040 \\
(0.034)\end{array}$ & $\begin{array}{l}0.066^{* * *} \\
(0.021)\end{array}$ \\
\hline R\&D to Sales & $\begin{array}{c}-2.383 \\
(2.346)\end{array}$ & $\begin{array}{c}1.468^{*} \\
(0.754)\end{array}$ & $\begin{array}{c}0.701 \\
(2.671)\end{array}$ & $\begin{array}{c}-3.437 \\
(2.593)\end{array}$ & $\begin{array}{c}-2.604 \\
(2.896)\end{array}$ & $\begin{array}{l}1.527^{*} \\
(0.784)\end{array}$ & $\begin{array}{c}1.458 \\
(1.879)\end{array}$ & $\begin{array}{c}-2.024 \\
(2.009)\end{array}$ \\
\hline Size & $\begin{array}{l}0.271 \text { ** } \\
(0.132)\end{array}$ & $\begin{array}{l}0.236 * * * \\
(0.084)\end{array}$ & $\begin{array}{c}0.031 \\
(0.093)\end{array}$ & $\begin{array}{c}-0.054 \\
(0.065)\end{array}$ & $\begin{array}{l}0.365^{* *} \\
(0.155)\end{array}$ & $\begin{array}{l}0.268 * * * \\
(0.088)\end{array}$ & $\begin{array}{c}0.029 \\
(0.090)\end{array}$ & $\begin{array}{c}-0.057 \\
(0.066)\end{array}$ \\
\hline Dummy Europe & $\begin{array}{c}-0.521 * \\
(0.284)\end{array}$ & $\begin{array}{c}-0.124 \\
(0.197)\end{array}$ & $\begin{array}{l}0.504 * * \\
(0.220)\end{array}$ & $\begin{array}{l}0.472 * * * \\
(0.136)\end{array}$ & $\begin{array}{c}-0.482 * \\
(0.287)\end{array}$ & $\begin{array}{c}-0.124 \\
(0.200)\end{array}$ & $\begin{array}{c}0.409 * \\
(0.228)\end{array}$ & $\begin{array}{l}0.375 \text { *** } \\
(0.140)\end{array}$ \\
\hline Dummy Japan & $\begin{array}{c}-2.703 * * \\
(1.138)\end{array}$ & $\begin{array}{c}-0.843 * \\
(0.506)\end{array}$ & $\begin{array}{c}0.078 \\
(0.657)\end{array}$ & $\begin{array}{c}0.451 \\
(0.356)\end{array}$ & $\begin{array}{c}-3.016^{* *} \\
(1.220)\end{array}$ & $\begin{array}{c}-1.020 * * \\
(0.519)\end{array}$ & $\begin{array}{c}0.117 \\
(0.646)\end{array}$ & $\begin{array}{c}0.470 \\
(0.370)\end{array}$ \\
\hline Dummy Pharma & $\begin{array}{c}-0.202 \\
(0.316)\end{array}$ & $\begin{array}{c}-0.671 * * * \\
(0.191)\end{array}$ & $\begin{array}{c}-1.316^{* * *} \\
(0.316)\end{array}$ & $\begin{array}{c}-0.668 * * * \\
(0.209)\end{array}$ & $\begin{array}{c}-0.154 \\
(0.339)\end{array}$ & $\begin{array}{c}-0.736^{* * *} \\
(0.201)\end{array}$ & $\begin{array}{c}-1.132 * * * \\
(0.292)\end{array}$ & $\begin{array}{c}-0.542 * * * \\
(0.189)\end{array}$ \\
\hline Environmental turbulence & & & & & $\begin{array}{c}-0.319 * * * \\
(0.118)\end{array}$ & $\begin{array}{c}-0.211 * * \\
(0.107)\end{array}$ & $\begin{array}{c}-0.568 * * * \\
(0.116)\end{array}$ & $\begin{array}{c}-0.377 \text { *** } \\
(0.077)\end{array}$ \\
\hline Technological newness & & & & & $\begin{array}{l}0.101 * * * \\
(0.037)\end{array}$ & $\begin{array}{c}-0.017 \\
(0.031)\end{array}$ & $\begin{array}{c}-0.174 * * * \\
(0.037)\end{array}$ & $\begin{array}{c}-0.146^{* * *} \\
(0.020)\end{array}$ \\
\hline Technological distance & & & & & $\begin{array}{l}1.632 * * * \\
(0.510)\end{array}$ & $\begin{array}{c}-0.653 * * \\
(0.293)\end{array}$ & $\begin{array}{c}0.417 \\
(0.412)\end{array}$ & $\begin{array}{c}0.110 \\
(0.244)\end{array}$ \\
\hline Prior cooperation & & & & & $\begin{array}{c}0.133 \\
(0.151)\end{array}$ & $\begin{array}{l}0.421 * * * \\
(0.122)\end{array}$ & $\begin{array}{l}0.397^{* * * *} \\
(0.143)\end{array}$ & $\begin{array}{c}0.100 \\
(0.122)\end{array}$ \\
\hline Log likelihood & -2120.17 & & & & -2057.56 & & & \\
\hline Prob $>\mathrm{Chi}^{2}$ & 0.0000 & & & & 0.0000 & & & \\
\hline Pseudo $R^{2}$ & 0.1299 & & & & 0.1556 & & & \\
\hline
\end{tabular}

Non-equity, technology alliances is the comparison group.

Year dummy variables were included in the analyses, but not in the table.

Robust standard errors in parentheses.

$N=1810$.

* Significant at $10 \%$.

** Significant at $5 \%$.

*** Significant at $1 \%$

a positive, significant effect is found of the likelihood to use CVC investments over non-equity alliances under higher levels of technological distance. However, technological distance between partners does also lead to a preference for non-equity alliances over minority holdings, and no differential effect is found between non-equity alliances and joint ventures and M\&As. The odds ratios in Table 3 furthermore show that when technological distance between firms increases, there is an increased tendency to use CVC investments over non-equity alliances and non-equity alliances over minority holdings. CVC investments are also preferred over joint ventures and M\&As, which in turn are preferred over minority holdings. Hence, there is no linear relationship between technological distance and the governance modes discussed here, since we find partial evidence for both Hypotheses $3 \mathrm{a}$ and $3 \mathrm{~b}$. The strong preference for CVCs to source externally developed technology that is distant from the focal firms technology core shows the particular role CVC investments play in external technology sourcing.

Based on the results in Tables 2 and 3, we find some evidence for Hypothesis $4 \mathrm{a}$ as well as for Hypothesis $4 \mathrm{~b}$. Hypothesis $4 \mathrm{a}$ predicts that prior cooperation has a positive effect on the use of more integrated governance modes, 
Table 3

Effect of the independent variables on the choice between external governance modes ( $\left.e^{\wedge} \mathrm{bStdX}\right)(a)$

\begin{tabular}{|c|c|c|c|c|c|c|c|c|c|c|c|}
\hline & SD & $\begin{array}{l}\text { CVC over } \\
\text { SA }\end{array}$ & $\begin{array}{l}\text { MH over } \\
\text { SA }\end{array}$ & $\begin{array}{l}\text { JV over } \\
\text { SA }\end{array}$ & $\begin{array}{l}\text { M\&A over } \\
\text { SA }\end{array}$ & $\begin{array}{l}\text { MH over } \\
\text { CVC }\end{array}$ & $\begin{array}{l}\text { JV over } \\
\text { CVC }\end{array}$ & $\begin{array}{l}\text { M\&A over } \\
\text { CVC }\end{array}$ & $\begin{array}{l}\text { JV over } \\
\mathrm{MH}\end{array}$ & $\begin{array}{l}\text { M\&A over } \\
\text { MH }\end{array}$ & $\begin{array}{l}\text { M\&A over } \\
\text { JV }\end{array}$ \\
\hline $\begin{array}{c}\text { Environmental } \\
\text { turbulence }\end{array}$ & 1.41 & $\begin{array}{l}0.6378 \\
\mathrm{SA}>\mathrm{CVC} \\
\mathrm{SA}>\mathrm{MH}>\end{array}$ & $\begin{array}{l}0.7426 \\
>\mathrm{JV} \\
\mathrm{M} \& \mathrm{~A}>\mathrm{J}\end{array}$ & 0.4492 & 0.5882 & n.s. & 0.7043 & n.s. & 0.6049 & 0.7921 & 1.3095 \\
\hline $\begin{array}{l}\text { Technological } \\
\text { newness }\end{array}$ & 3.29 & $\begin{array}{l}1.3944 \\
\mathrm{CVC}>\mathrm{SA},\end{array}$ & $\begin{array}{l}\text { n.s. } \\
\text { MH }>J V,\end{array}$ & $\begin{array}{l}0.5647 \\
M \& A\end{array}$ & 0.6188 & 0.6776 & 0.4050 & 0.4438 & 0.5976 & 0.6549 & n.s. \\
\hline $\begin{array}{l}\text { Technological } \\
\text { distance }\end{array}$ & 0.28 & $\begin{array}{l}1.5674 \\
\mathrm{CVC}>\mathrm{SA} \\
\mathrm{CVC}>\mathrm{JV}\end{array}$ & $\begin{array}{l}0.8354 \\
>\mathrm{MH} \\
\mathrm{M} \& \mathrm{~A}>\mathrm{M}\end{array}$ & n.s. & n.s. & 0.5330 & 0.7155 & 0.6577 & 1.3426 & 1.2340 & n.s. \\
\hline $\begin{array}{l}\text { Prior } \\
\quad \text { cooperation }\end{array}$ & 0.61 & $\begin{array}{l}\text { n.s. } \\
\text { MH, JV > S } \\
\text { MH }>\text { CVC }\end{array}$ & $\begin{array}{l}1.2927 \\
A, M \& A\end{array}$ & 1.2733 & n.s. & 1.1921 & n.s. & n.s. & n.s. & 0.8221 & 0.8346 \\
\hline
\end{tabular}

Table reports change in odds for SD increase of X based on Model 2 in Table 2. n.s. $=$ not significant.

whereas Hypothesis $4 \mathrm{~b}$ predicts the opposite. Prior cooperation with a partnering firm increases the likelihood of using minority holdings and joint ventures as opposed to non-equity alliances, though the results in Table 3 show no significant result for the choice between joint ventures and minority holdings. Table 3 furthermore shows some preference for minority holdings and joint ventures over strategic alliances and M\&As, which points in the direction of both Hypotheses $4 \mathrm{a}$ and $4 \mathrm{~b}$.

To shed some more light on the propensity of firms to use a particular type of governance under certain levels of uncertainty, we have calculated the predicted probabilities under varying levels of both exogenous and endogenous uncertainty. Recall that exogenous uncertainty incorporates environmental turbulence and technological newness, and that endogenous uncertainty is proxied by technological distance and prior cooperation.

Table 4 shows that when both exogenous and endogenous uncertainty decreases, the predicted use of more integrated governance modes increases, whereas the likelihood of strategic alliances decreases significantly. Moreover, when both types of uncertainty are high, i.e. when the relationship is subject to maximum uncertainty, less integrated governance modes are preferred over more integrated ones. However, the situations in which only one type of uncertainty is high and the other one is low are interesting. When looking for instance at the situation in which endogenous uncertainty is low and exogenous uncertainty is high, the likelihood of using non-equity alliances increases from 47 to $69 \%$, showing the importance of flexibility when the source of the uncertainty is beyond control of the firm. However, when exogenous uncertainty is low and endogenous uncertainty is high, the propensity to use M\&As increases from 34 to $51 \%$. Thus, explaining how firms source technologies for new business development under varying levels of uncertainty requires the combination of multiple perspectives on uncertainty.

The results for the control variables also deserve some attention. The dummy variables indicate that the pharmaceutical companies are more involved in technology alliances and less in minority holdings, joint ventures and acquisitions. There are also institutional influences: both Asian and European companies prefer alliances over CVC investments. In addition, large firms prefer CVC investments and minority holdings to non-equity alliances. Finally, prior experience with a particular governance mode is not per se related to a preference for that mode over another. As shown in Table 2, alliance experience has a positive effect on the choice of alliances over CVC investments, minority

Table 4

Predicted probabilities

\begin{tabular}{|c|c|c|c|c|c|c|c|c|c|c|}
\hline & \multicolumn{5}{|c|}{ Low exogenous uncertainty } & \multicolumn{5}{|c|}{ High exogenous uncertainty } \\
\hline & SA & $\mathrm{CVC}$ & $\mathrm{MH}$ & JV & M\&A & SA & $\mathrm{CVC}$ & MH & JV & $\mathrm{M} \& \mathrm{~A}$ \\
\hline All variables to sample mean & 47 & 4 & 10 & 5 & 34 & 47 & 4 & 10 & 5 & 34 \\
\hline Low endogenous uncertainty & 29 & 2 & 8 & 9 & 52 & 69 & 3 & 10 & 1 & 17 \\
\hline High endogenous uncertainty & 23 & 4 & 8 & 14 & 51 & 62 & 8 & 10 & 2 & 18 \\
\hline
\end{tabular}

Predicted probabilities with all other variables in the sample mean.

Non-dummy variables are taken as mean plus (high) or minus (low) one standard deviation (Belderbos and Sleuwaegen, 2005). 
holdings, and M\&As, but no effect on the choice of joint ventures. Similarly, CVC experience is related to the choice of CVC investments over strategic alliances, but also to the choice of M\&As over alliances, and alliances over minority holdings. Experience with M\&As increases the likelihood of choosing M\&As over alliances, and interestingly, minority holdings and joint venture experience does not lead to the choice of any of the governance modes over alliances. Although prior studies have argued that firms build governance-form specific capabilities through the experience with different governance modes (e.g. Dyer and Singh, 1998; Rothaermel and Deeds, 2006; Villalonga and McGahan, 2005), our results suggest that this does not necessarily lead to a preference for that particular governance mode over another.

\section{Discussion and conclusions}

In this study we have tested the effect of both exogenous and endogenous uncertainty on the choice between nonequity technology alliances, corporate venture capital investments, minority holdings, joint ventures and mergers and acquisitions. We tested several hypotheses about the impact of exogenous and endogenous uncertainty on this choice. The results provide varying levels of support for these hypotheses.

In the discussion leading to the first hypothesis we have argued that there is a positive relationship between high environmental uncertainty and the use of less integrated governance modes. Although the preference for CVC over minority holdings and M\&As is still unclear, the results show how non-equity alliances are the preferred mechanism to deal with unforeseen contingencies, whereas joint ventures are the least favorable. This is consistent with prior studies on environmental turbulence (e.g. Folta, 1998; Moon, 1998; Santoro and McGill, 2005), indicating that under higher levels of environmental turbulence, companies need to remain flexible, by making small, reversible investments. Contrary to our expectations, M\&As are not the least preferred option. Although this seems to be somewhat surprising, it should be noted that in the pharmaceutical sector, the acquisition of small biotech companies is an important mechanism to gain access to new technologies. Even under high levels of environmental turbulence, acquiring a small firm can be more attractive than setting up a whole new organizational entity (i.e. joint venture).

The second hypothesis predicted that a higher level of technological newness of the partner firm will lead to an increased use of less integrated governance modes. We hypothesized that due to the highly uncertain outcomes, flexibility to withdraw from the commitment is an important asset companies need to cope with this uncertainty. The results only partially confirm the hypotheses, suggesting a preference for non-equity alliances and minority holdings over joint ventures and M\&As, though showing that CVC investments are clearly preferred to the other governance modes. Prior research also indicated the preference for strategic alliances over M\&As in the earlier stages of the technology life cycle (e.g. Lambe and Spekman, 1997), but their discussion is restricted to these two governance modes. On the other hand, researchers studying the use of CVC investments have pointed towards the fact that these investments are particularly oriented towards "having a window on emerging technologies" (Chesbrough, 2002; Dushnitsky and Lenox, 2006; Keil, 2002; Siegel et al., 1988) and that firms are more likely to invest CVC in the presence of technological opportunities (Dushnitsky and Lenox, 2005b), which might explain why CVC investments are preferred over strategic, non-equity alliances. In addition, although the possible outcomes of emerging technologies are uncertain, the possible return when an emerging technology turns out to be a success is much higher compared to the more incremental innovations based on mature technologies (Ahuja and Lampert, 2001). This might induce companies facing new technologies to opt for equity strategies in order to get some control and as the creation of an option for the future.

The alternative Hypotheses $3 \mathrm{a}$ and $3 \mathrm{~b}$ predicted that technological distance between partnering firms induces the firms to use less (more) integrated governance modes. We found mixed results, partially confirming both hypotheses. Although the results show no effect for the use of strategic alliances as opposed to joint ventures and M\&As under these circumstances, the outcomes show once more a clear preference among companies to source distant technologies through CVC arrangements. This effect for CVC investments corresponds with the findings of Dushnitsky (2004). He analyzed the relationship between an investing firm and an entrepreneur and came to the conclusion that this relationship is less likely to materialize when the products of the two are substitutes, i.e. when both parties operate in the same industry. The results also provide some evidence for the largely explorative nature of CVC investments. Interestingly, the results also show a clear differential effect for CVC investments and minority holdings, supporting our arguments that although CVC and minority holdings can both be regarded as minority equity investments, they are clearly used by investing firms as two distinct mechanisms of external technology sourcing. 
The last two alternative Hypotheses (4a and b) predicted a positive effect of prior cooperation the use of more (less) integrated governance modes. We find that minority holdings and joint ventures are preferred over non-equity alliances, but we also find that these strategies are preferred over M\&As. Although this might indicate some support for both Hypotheses $4 \mathrm{a}$ and $4 \mathrm{~b}$, one should be careful when interpreting these results. After a strategic alliance or CVC investment, the investing firm might opt to increase commitment and take a minority participation in its partner or form a joint venture. In line with earlier findings of Hagedoorn and Sadowski (1999), our results also show that prior cooperation does not necessarily lead to an M\&A.

Another important finding of this study is that we found no empirical support for the proposition that different interorganizational modes can be ranked along a market-hierarchy continuum as has been argued by many scholars on theoretical grounds (e.g. Gulati and Singh, 1998; Hagedoorn and Sadowski, 1999; Nielsen, 2002; Santoro and McGill, 2005; Villalonga and McGahan, 2005; Williamson, 1985). The results of the Brant test prove that ranking external governance choices (by means of an ordinal logit regression) to reflect the market-hierarchy continuum is not supported by the data. The multinomial logit estimates show that some ranking among the governance modes is possible, but they also suggest that this ranking is not linear as suggested by the previously mentioned continuum. On the contrary, the ranking is sometimes partial and is to some extent different depending on the proxies we have used for both external and relational uncertainty. The benefits of using a particular type of external technology sourcing mode are contingent on the external and relational uncertainty. This implies that each governance mode has its own strengths and weaknesses to cope with environmental turbulence, emerging technologies, technological distance between partners and technology sourcing in the wake of prior cooperation. Hence, the empirical analysis suggests that companies make use of different external technology sourcing modes depending on the type of uncertainty they have to cope with. External technology sourcing is contingent on the type of uncertainty, which, in turn, leads to a more complex understanding of external technology sourcing as suggested by the continuum in terms of more or less integrated modes.

Overall, we think that this paper contributes to three main areas of the study: First, we have highlighted the role of uncertainty in governance mode choice, an important and often understudied topic. Furthermore we increased the theoretical and empirical importance of this paper by expanding number of mode-types compared to previous studies. Including all external governance modes provides an insight in how firms really decide about external technology sourcing. This is an important feature because it reflects the current state of external venturing in which firms have a full array of options to fulfill their basic needs for technology development and acquisition. Finally, the empirical results give evidence that a linear continuum of external technology modes as has been suggested in the literature is too simplistic to understand the technology based cooperation between innovating firms and should be replaced by a multidimensional construct in which each governance mode plays a unique role.

The current study clearly has a number of limitations. First, prior cooperation between the two firms in the dyad should be decomposed into the different types of external technology sourcing modes. As suggested in the literature streams on real options, certain types of investment might be considered as the creation of an option, which might be exercised at a later point in time using a more integrated solution (e.g. Bowman and Hurry, 1993; Hagedoorn and Sadowski, 1999; Haspeslagh and Jamison, 1991; Kogut, 1991; Vanhaverbeke et al., 2002). If we want to shed more light on this theory, it is necessary to split up prior cooperation into the specific modes in which prior cooperation existed. Next, prior cooperation should also be differentiated in terms of the partner's characteristics: a minority holding in a small (high-tech) firm will probably have a different effect on follow-up cooperative agreements compared to a minority holding in larger firms.

Furthermore, although we have tested the impact of different types of uncertainty on governance mode choice, future research should also look into the possible moderating effects of uncertainty. For instance, prior cooperation might interact with the effect of different types of uncertainty on governance mode choice. Moreover, the effect of uncertainty on governance mode decisions might differently affect industry leaders and laggards. ${ }^{8}$

An additional limitation of this study stems from the lack of data about partners and the relationship under study. In many cases partners are small firms that are not publicly owned but financed by private equity owners. As a result, it is extremely difficult to obtain financial information about these partners. This limitation excludes the possibility to measure the impact of partner characteristics on the choice of focal firms between external governance modes. Moreover, it might be the case that inter-firm ties differ along various dimensions, other than the ones discussed here. Prior studies have already noted that the market-hierarchy continuum is not sufficient to explain the broad array of governance modes (e.g. Powell, 1990). Following our analysis, we believe that the organization of inter-firm ties is in

\footnotetext{
${ }^{8}$ We thank one anonymous reviewer for pointing us to this.
} 
fact a multidimensional construct. CVC investments are specifically oriented towards young technologies in an early stage of development. As such, the advantage of using CVC investments should not only be seen in light of their flexibility, but also because of the unique proposition of CVC investments to cope with new technologies. Specific attributes of CVC investments include the fact that they can be regarded as small learning investments and that they are often used as a first encounter with new technologies. Moreover, it is very likely that different resources are funneled through different modes. For example, non-equity alliances could serve solely for technological-collaboration whereas CVC is a channel to distribute capital as well. Further research should analyze how different modes channel these different types of resources. In addition, including more information on the inter-firm relationship level enables further insight on the impact of collaboration-specific issues.

Moreover, this is to our knowledge the first empirical study comparing CVC investments with strategic alliances and mergers and acquisitions as alternative modes to source externally developed technology. Hence, additional research in this area might be fruitful. Although CVC investments do impose a condition on the partner firm, i.e. the partner firm should be a start-up, its value as an alternative and complementary means to get access to new technologies is apparent. Further research in this field could go into the direction of not only predicting when CVC should be preferred over other governance modes, but should also focus on the advantages and disadvantages of this mode for technology sourcing as opposed to the other the other modes. One topic which definitely needs more attention is the differential impact of these technology sourcing modes on the innovation and financial performance of focal firms.

\section{Acknowledgements}

The authors would like to thank René Belderbos, Johan Maes, Nadine Roijakkers, Wendy van der Valk, and two anonymous reviewers for their helpful comments and suggestions on earlier versions of this paper.

\section{References}

Ahuja, G., 2000. Collaboration networks, structural holes, and innovation: a longitudinal study. Administrative Science Quarterly 45, 425-455.

Ahuja, G., Katila, R., 2001. Technological acquisitions and the innovation performance of acquiring firms: a longitudinal study. Strategic Management Journal 22, 197-220.

Ahuja, G., Lampert, C.M., 2001. Entrepreneurship in the large corporation: a longitudinal study of how established firms create breakthrough ideas. Strategic Management Journal 22, 521-543.

Allen, S.A., Hevert, K.T., 2007. Venture capital investing by information technology companies: did it pay? Journal of Business Venturing 22, $262-282$. Balakrishnan, S., Wernerfelt, B., 1986. Technical change, competition and vertical integration. Strategic Management Journal 7 (4), $347-359$.

Balakrishnan, S., Koza, M.P., 1993. Information asymmetry, adverse selection and joint ventures: theory and evidence. Journal of Economic Behavior and Organization 20, 99-117.

Belderbos, R., Sleuwaegen, L., 2005. Competitive drivers and international plant configuration strategies: a product-level test. Strategic Management Journal 26, 577-593.

Bowman, E.H., Hurry, D., 1993. Strategy through the option lens: an integrated view of resource investments and the incremental choice process. Academy of Management Review 18 (4), 760-782.

Brant, R., 1990. Assessing proportionality in the proportional odds model for ordinal logistic regression. Biometrics 46, $1171-1178$.

Cantwell, J., Colombo, M.G., 2000. Technological and output complementarities: inter-firm cooperation in information technology ventures. Journal of Management and Governance 4, 117-147.

Chesbrough, H., 2002. Making sense of corporate venture capital. Harvard Business Review, March 2002, 4-11.

Cohen, W.M., Levinthal, D.A., 1990. Absorptive capacity: a new perspective on learning and innovation. Administrative Science Quarterly 35, $128-152$.

Colombo, M.G., 2003. Alliance form: a test of the contractual and competence perspectives. Strategic Management Journal 24, $1209-1229$.

Dess, G.G., Lumpkin, G.T., Covin, J.G., 1997. Entrepreneurial strategy making and firm performance: tests of contingency and configuration models. Strategic Management Journal 18 (9), 677-695.

Dess, G.G., Ireland, R.D., Zahra, S.A., Floyd, S.W., Janney, J.J., Lane, P.J., 2003. Emerging issues in corporate entrepreneurship. Journal of Management 29 (3), 351-378.

Dougherty, D., 1995. Managing your core incompetence for corporate venturing. Entrepreneurship: Theory \& Practice 19 (3), $113-135$.

Dushnitsky, G., 2004. Limitations to Inter-Organizational Knowledge Acquisition. Academy of Management Best Paper Proceedings.

Dushnitsky, G., Lenox, M.J., 2005a. When do incumbents learn from entrepreneurial ventures? Corporate venture capital and investing firm innovation rates. Research Policy 34 (5), 615-639.

Dushnitsky, G., Lenox, M.J., 2005b. When do firms undertake R\&D by investing in new ventures? Strategic Management Journal 26, 947-965.

Dushnitsky, G., Lenox, M.J., 2006. When does corporate venture capital investment create firm value? Journal of Business Venturing 21 (6), 753-772.

Duysters, G.M., De Man, A.P., 2003. Transitory alliances: an instrument for surviving turbulent industries. R\&D Management 33 (1), 49-58.

Dyer, J., Singh, H., 1998. The relational view: cooperative strategy and sources of interorganizational competitive strategy. Academy of Management Review 23, 660-679. 
Folta, T.B., 1998. Governance and uncertainty: the trade-off between administrative control and commitment. Strategic Management Journal 19, $1007-1028$.

Folta, T.B., Leiblein, M.J., 1994. Technology acquisition and the choice of governance by established firms: insights from option theory in a multinomial logit model. Academy of Management Proceedings, pp. 27-31.

Folta, T.B., Miller, K.D., 2002. Real options in equity partnerships. Strategic Management Journal 23, 77-88.

Garette, B., Dussauge, P., 2000. Alliances versus acquisitions: choosing the right option. European Management Journal 18 (1), $63-69$.

George, G., Zahra, S.A., Wood, D.R., 2002. The effects of business-university alliances on innvative output and financial performance: a study of publicly traded biotechnology companies. Journal of Business Venturing 17, 577-609.

Grilliches, Z., 1979. Issues in assessing the contribution of research and development to productivity growth. Bell Journal of Economics 10, 92-116.

Gulati, R., 1995. Does familiarity breed trust? The implications of repeated choice for contractual ties in alliances. Academy of Management Journal 38 (1), 85-112.

Gulati, R., Singh, H., 1998. The architecture of cooperation: managing coordination uncertainty and interdependence in strategic alliances. Administrative Science Quarterly 43 (4), 781-814.

Gulati, R., Garguilo, M., 1999. Where do interorganizational networks come from? American Journal of Sociology 104 (5), $1439-1493$.

Hagedoorn, J., 1993. Understanding the rationale of strategic technology partnering: interorganizational modes of cooperation and sectoral differences. Strategic Management Journal 14, 371-385.

Hagedoorn, J., Sadowski, B., 1999. The transition from strategic technology alliances to mergers and acquisitions: an exploratory study. Journal of Management Studies 36 (1), 87-107.

Hagedoorn, J., Duysters, G.M., 2002. External sources of innovative capabilities: the preference for strategic alliances or mergers and acquisitions. Journal of Management Studies 39 (2), 167-188.

Haspeslagh, G., Jemison, D.B., 1991. Managing acquisitions: creating value through corporate acquisition activity. Free Press, New York.

Hausman, J.A., McFadden, D.L., 1984. Specification tests for the multinomial logit model. Econometrica 52 (5), 1219-1240.

Hitt, M.A., Hoskisson, R.E., Ireland, R.D., Harrison, J.S., 1991. Effects of acquisitions on R\&D inputs and outputs. Academy of Management Journal $34(3), 693-706$.

Hitt, M.A., Hoskisson, R.E., Johnson, R.A., Moesel, D.D., 1996. The market for corporate control and firm innovation. Academy of Management Journal 39 (5), 1084-1119.

Hitt, M.A., Ireland, R.D., Lee, H., 2000. Technological learning, knowledge management, firm growth and performance: an introductory essay. Journal of Engineering and Technology Management 17, 231-246.

Hitt, M.A., Ireland, R.D., Camp, S.M., Sexton, D.L., 2001. Guest editors' introduction to the special issue strategic entrepreneurship: entrepreneurial strategies for wealth creation. Strategic Management Journal 22 (6-7), 479-491.

Hoffmann, W.H., Schaper-Rinkel, W., 2001. Acquire or ally? A strategy framework for deciding between acquisition and cooperation. Management International Review 41 (2), 131-159.

Janney, J.J., Dess, G.G., 2004. Can real-options analysis improve decision-making? Promises and pitfalls. Academy of Management Executive 18 (4), 75.

Jaffe, A.B., 1986. Technological opportunity and spillovers of R \& D: evidence from firms' patents, profits, and market value. The American Economic Review 76 (5), 984-1001.

Jones, G.K., Lanctot, A., Teeegen, H.J., 2001. Determinants and performance impacts of external technology acquisition. Journal of Business Venturing 16, $255-283$.

Katila, R., Ahuja, G., 2002. Something old, something new: a longitudinal study of search behavior and new product introductions. Academy of Management Journal 45 (6), 1183-1194.

Keil, T., 2002. External Corporate Venturing: Strategic Renewal in Rapidly Changing Industries. Quorum, Westport, CT.

Kogut, B., 1991. Joint ventures and the option to expand and acquire. Management Science 37, 19-33.

Lambe, C.J., Spekman, R.E., 1997. Alliances, external technology acquisition, and discontinuous technology change. Journal of Product Innovation Management 14 (2), 102-116.

Lane, P.J., Lubatkin, M., 1998. Relative absorptive capacity and interorganizational learning. Strategic Management Journal, 19, 461-477.

Long, J.S., Freese, J., 2003. Regression models for categorical dependent variables using stata. Stata Press, College Station, TX.

Mahoney, J.T., 1992. The choice of organizational form: vertical financial ownership versus other methods of vertical integration. Strategic Management Journal 13 (8), 559-584.

Moon, C.W., 1998. Technological capacity as a determinant of governance form in international strategic combinations. Journal of High technology Management Research 9 (1), 35-53.

Mowery, D.C., Oxley, J.E., Silverman, B.S., 1996. Strategic alliances and interfirm knowledge transfer. Strategic Management Journal 17, 77-91.

Nielsen, B.B., 2002. Synergies in strategic alliances: motivation and outcomes of complementary and synergistic knowledge networks. Journal of Knowledge Management Practice October 2002, http://www.tlainc.com/articl43.htm.

Nooteboom, B., 2004. Governance and competence: how can they be combined? Cambridge Journal of Economics 28 (4), 505-525.

O’Brien, J.P., Folta, T.B., Johnson, D.R., 2003. A real options perspective on entrepreneurial entry in the face of uncertainty. Managerial and Decision Economics 24, 515-533.

Patel, P., Pavitt, K., 1997. The technological competencies of the world's largest firms: complex and path-dependent, but not much variety. Research Policy 26 (2), 141-156.

Pisano, G.P., 1990. The R\&D boundaries of the firm: an empirical analysis. Administrative Science Quarterly 35 (1), $153-176$.

Powell, W.W., 1990. Neither market nor hierarchy: network form of organization. In: Staw, B.M., Cummings, L.L. (Eds.), Research in organizational behavior, vol. 12. JAI Press Inc., Greenwich, Conn, pp. 295-336.

Powell, W.W., DiMaggio, P.J., 1991. The New Institutionalism in Organizational Analysis. The University of Chicago Press, Chicago. 
Reuer, J.J., Ariño, A., Mellewigt, T., 2006. Entrepreneurial alliances as contractual forms. Journal of Business Venturing 21, 306-325.

Reuer, J.J., Koza, M.P., 2000. Asymmetric information and joint venture performance: theory and evidence for domestic and international joint ventures. Strategic Management Journal 21 (1), 81-88.

Ring, P.S., Van de Ven, A.H., 1994. Developmental processes of cooperative interorganizational relationships. Academy of Management Review 19 (1), 90-118.

Roberts, E.B., Berry, C.A., 1985. Entering new businesses: selecting strategies for success. Sloan Management Review 26, 3-17.

Roberts, E.B., Liu, W.K., 2001. Ally or acquire? How technology leaders decide. MIT Sloan Management Review 43 (1), $26-34$.

Rothaermel, F.T., Deeds, D.L., 2006. Alliance type, alliance experience, and alliance management capability in high-technology ventures. Journal of Business Venturing 21, 429-460.

Sahal, D., 1985. Technological guideposts and innovation avenues. Research Policy 14 (2), 61-82.

Santoro, M.D., McGill, J.P., 2005. The effect of uncertainty and asset co-specialization on governance in biotechnology alliances. Strategic Management Journal 26, 1261-1269.

Sampson, R.C., 2004. Organizational choice in R\&D alliances: knowledge based and transaction cost perspective. Managerial and Decision Economics 25, 421-436.

Schildt, H.A., Maula, M.V.J., Keil, T., 2005. Explorative and exploitative learning from external corporate ventures. Entrepreneurship Theory \& Practice 29 (4), 493-515.

Siegel, R., Siegel, E., MacMillan, I., 1988. Corporate venture capitalists: autonomy, obstacles and performance. Journal of Business Venturing 3, $233-247$.

Steensma, H.K., Fairbank, J.F., 1999. Internalizing external technology: a model of governance mode choice and an empirical assessment. The Journal of High Technology Management Research 10 (1), 1-35.

Stevenson, H.H., Jarillo, J.C., 1990. A paradigm of entrepreneurship: entrepreneurial management. Strategic Management Journal 11 (special issue), $17-27$.

Stuart, T.E., 2000. Interorganizational alliances and the performance of firms: a study of growth and innovation rates in high-technology industry. Strategic Management Journal 21, 791-811.

Sutcliffe, K.M., Zaheer, A., 1998. Uncertainty in the transaction environment: an empirical test. Strategic Management Journal 19 (1), 1-23.

Teng, B.-S., 2003. Corporate entrepreneurship through strategic alliances: a resource-based framework. Paper presented at the Academy of Management Annual Meeting, August 1-6 (Seattle, U.S.A.).

Tsai, K.-H., Wang, J.-C., 2008. External technology acquisition and firm performance. Journal of Business Venturing 23 (1), 91-112.

Vanhaverbeke, W., Duysters, G., Noorderhaven, N., 2002. External technology sourcing through alliances or acquisitions: an analysis of the application-specific integrated circuits industry. Organization Science 13 (6), 714-733.

Van de Vrande, V., Lemmens, C., Vanhaverbeke, W., 2006. Choosing governance modes for external technology sourcing. R\&D Management 36 (3), $347-363$.

Vassolo, R.S., Anand, J., Folta, T.B., 2004. Non-additive in portfolios of exploration activities: a real options-based analysis of equity alliances in biotechnology. Strategic Management Journal 25, 1045-1061.

Villalonga, B., McGahan, A.M., 2005. The choice among acquisitions, alliances and divestures. Strategic Management Journal 26, $1183-1208$.

Wadhwa, A., Kotha, S., 2006. Knowledge creation through external venturing: evidence from the telecommunications equipment manufacturing industry. Academy of Management Journal 49 (4), 819-835.

Williamson, O.E., 1975. Markets and Hierarchies: Analysis and Antitrust Implications. The Free Press, New York.

Williamson, O.E., 1985. The Economic Institutions of Capitalism: Films, Markets, Relational Contracting. Free Press, New York.

Zahra, S.A., Bogner, W.C., 1999. Technology strategy and software new ventures' performance: exploring the moderating effect of the competitive environment. Journal of Business Venturing 15 (2), 135-173. 